\title{
Differential blood leukocyte populations based on individual variances and age
}

\author{
Jane Kasten-Jolly ${ }^{1}$. David A. Lawrence ${ }^{1,2}$
}

Received: 26 August 2021 / Accepted: 9 December 2021 / Published online: 13 January 2022

(c) The Author(s), under exclusive licence to Springer Science+Business Media, LLC, part of Springer Nature 2021

\begin{abstract}
Blood was collected from the New York State Department of Health (NYSDOH) employees to assess variances in leukocyte numbers in January, May, and September throughout a year and over many years. Women and men of ages 20 to 80 volunteered to donate for this program. Most of the blood came from healthy individuals, and many remained healthy throughout the years of their blood donations. The major objective was to determine the extent that blood leukocyte numbers change so that transient vs more lingering changes may be helpful in assessing health status. Since some donors remained in the program for 14 years, age influences over time could be determined. Within a short period of 2-3 years, the flow cytometric immunophenotypic profile of blood lymphocyte is relatively stable with a CV\% of $<20 \%$. However, as humans age, the blood $\mathrm{CD}^{+} \mathrm{T}$ cell, $\mathrm{CD} 8^{+} \mathrm{T}$ cell, $\mathrm{B}$ cell, NKT cell, and $\mathrm{CD} 4^{-} / \mathrm{CD}^{-}$double-negative $\mathrm{T}$ cell (DN-T cell) subsets declined in cell numbers $/ \mu \mathrm{L}$, but the double-positive $\mathrm{CD} 4^{+} / \mathrm{CD} 8^{+} \mathrm{T}$ cells (DP-T cells) increased in numbers. The extent and chronology of a variance, e.g., a subset exceeding its 75th or 90th percentile, might be indicative of a transient or chronic physiological or psychosocial stress affecting health or a developing pathology; however, because of the wide ranges of cell numbers $/ \mu \mathrm{L}$ for each subset among individuals reported as healthy, everyone's immunity and health must be carefully evaluated. A CD4 to $\mathrm{CD} 8$ ratio (4/8R) of $<1$ has been used to define an immunodeficiency such as HIV-induced AIDS, but a high 4/8R is less well associated with health status. A high 4/8R or granulocyte to lymphocyte ratio (GLR) might be an indicator of a stress, infection, or immune-related pathology. Sporadic and longitudinal increases of GLRs are reported. The results suggest that there are some age and sex differences in leukocyte numbers; stress influences on the blood profile of leukocytes likely exist. However, some values exceeding 2 standard deviations from means do not necessarily predict a health concern, whereas a longitudinal increase or decline might be indicative of a need for further evaluations.
\end{abstract}

Keywords Granulocytes $\cdot$ Lymphocytes $\cdot$ T cell subsets $\cdot$ Age $\cdot$ Sex $\cdot$ Stress $\cdot$ NK cells $\cdot$ NKT cells

\section{Introduction}

As with all clinical measurements, it is critical to establish accurate normal ranges and to know whether any aberrant result is a transient change or a more consistent concern requiring medical attention. A transient change may relate to a psychosocial stress, which is known to alter a blood profile $[1,2]$; psychosocial stress may be benign or a sign of future ill health. Any longitudinal increase in a particular blood

David A. Lawrence

david.lawrence@health.ny.gov

1 Wadsworth Center, New York State Department of Health, Albany, NY 12208, USA

2 School of Public Health, University of Albany, Rensselaer, NY, USA leukocyte pattern may be indicative of a developing pathology. It may be especially difficult to determine accurate measurements for minor $\mathrm{T}$ cell subunits since some clinical immunology labs do not include $\mathrm{CD} 3^{+} / \mathrm{CD}^{+} / \mathrm{CD}^{+}$doublepositive $\mathrm{T}$ cells (DP-T cells), $\mathrm{CD} 3^{+} / \mathrm{CD}^{-} / \mathrm{CD} 8^{-}$doublenegative $\mathrm{T}$ cells (DN-T cells), or $\mathrm{CD} 3{ }^{+} \mathrm{CD} 16^{+} \mathrm{CD} 56^{+} \mathrm{NKT}$ cells in their patients' reports, and these subsets have clinical significance [3]. The difficulty with quantifying minor subsets can be averted with inclusion of flow cytometric gates on viable and non-aggregated cells, proper settings for the $\mathrm{CD} 3{ }^{+} \mathrm{CD} 45^{\text {hi }} \mathrm{SSC}^{\text {low }} \mathrm{T}$ cells, and collecting a minimum of $10^{4}$ cells in the lymphocyte gate. Herein, leukocyte patterns are presented for longitudinal results in percentages and cell numbers $/ \mu \mathrm{L}$ for several individuals who were immunophenotyped at least 3 times per year, and for some over a 14-year period to give examples of relatively long-term 
individual variance, which in general was reasonably stable for relatively healthy individuals, including some $>60$ years of age. However, it often is determined that with increasing age, there is diminished adaptive immunity [4] and increased inflammaging or immunoaging [5, 6], which affects the levels of proinflammatory cytokines that may alter the leukocyte profile and may influence cancer incidence with age. Valiathan et al. [7] reported blood leukocyte levels from infants (1-7 months) to elderly (70-90 years) showing a decline in percentage of lymphocytes and an increase in percentage of neutrophils; the number of lymphocytes declined from children (1-6 years of age) to the older age groups (adolescents, 12-18 years; adults, 21-50 years; elderly, 70-92). For the lymphocyte population, only the percentage of B cells declined with age; the NK cell percentage increased from adults to elderly; DP-T, DN-T, and NKT cells were not measured. Plasma cytokine levels also were measured for the adult and elderly group, and IFN $\gamma, \mathrm{IL}-2, \mathrm{TNF} \alpha$, IL-6, and MCP-1 increased in the elderly group, suggesting greater inflammation [7].

Many different environmental stressors may enhance the balance between pro- and anti-inflammatory cytokines leading to immunosenescence [8] and age-related diseases [9, 10]. A high level of inflammation may enhance immunosenescence and enhance incidence of infections and cancers with age. Connection of inflammation with cancer was mentioned as early as 1863 by Virchow [11]. The role of inflammation is evident in several diseases, with obvious examples being rheumatoid arthritis (RA) and inflammatory bowel disease (IBD). With atrial fibrillation, an increase in the neutrophil-to-lymphocyte ratio (NLR) correlated with the proinflammatory cytokine IL-17 [12]. A concern with COVID19 has been high levels of proinflammatory cytokines and loss of immune cells [13]. SARS-COV-2 patients with more severe disease had high levels of neutrophils and lower levels of lymphocytes with higher levels of IL-6 [14].

A readily available indicator of systemic inflammation is the NLR, since neutrophils increase in the blood during inflammation and stress $[2,15]$. NLR values have been used for diagnosing cancers [16], cardiovascular disease and stroke [15, 17-21], and neurological diseases, such as depression and schizophrenia [22]. Elevated pre-treatment NLR values of patients with breast cancer [23], non-small cell lung cancer [24], gastric cancer [25], pancreatic cancer [26], and urothelial cancer [27] and many other cancers were prognostic for worse overall survival. In a mouse model of $1 \mathrm{~h}$ cold restraint stress, neutrophils were immediately trafficked from the bone marrow to blood due to sympathetic nervous system release of norepinephrine, which also creates oxidative stress and suppression of $\mathrm{T}$ cells [28]. NLR also was a measure of depression in rats [29]. Thus, due to the heterogeneity of neutrophils with suppressive or promoting effect on cancer [30] and the influence of psychological stress on the inflammasome [31] and the blood levels of neutrophils [2, 28, 32], it may be important to evaluate the NLR at multiple times. The positive beneficial influences of support groups for breast cancer patients [33] may be related to lessening the stress and lowering the NLR.

Since the lymphoid profile and NLR are markers for the general immune response to various stress stimuli and for diagnosing some major disorders, it is important to get more than a single value since there might be a transient increase due to a psychological and/or physical stress. Several studies have been performed to examine pre-operative NLR and survival in years for colorectal cancer (CRC) patients' post-surgery evaluations. Of these studies, 19 studies have been reviewed by Haram et al. [34], and it was concluded that a pre-operative NLR $>5$ was associated with a shortterm survival and increased mortality. However, it should be noted that the cutoff of an NLR of 5 was the highest value and the cutoffs for all the studies ranged from 2 to 5. Another report described a meta-analysis of 144 studies that examined the utility of the NLR as a prognostic tool for gastrointestinal cancer [35]. Here, too, the NLR cutoff values varied, but it was evident that the higher NLR resulted in a lower overall survival rate. NLR measurements in conjunction with other markers of inflammation, plateletlymphocyte ratio (PLR), carcinoembryonic antigen (CEA), carbohydrate antigen 19-9 (CA 19-9), lactate dehydrogenase (LDH), and C-reactive protein (CRP) were used to estimate survival percentages of CRC patients [36]; a NLR of 3 was used as the cutoff, and it was found that an NLR $>3.0$ dropped the probability of a 5-year survival down to 0.05 . In the case of cardiovascular diseases, monitoring the NLR is more important after the surgery has been performed to assess inflammation due to the procedure and to monitor the healing process. Interestingly, patients with psychiatric disorders, such as depression, have also been found to have elevated NLRs [37, 38]. As an inflammatory biomarker, clinicians have turned to NLR, because it is cost-effective and has been shown to have some clinical reliability in predicting patient overall survival.

In the study described herein, some subjects were followed with immunophenotyping for 14 years. Some of the volunteers were screened three times per year, and their lymphoid subsets and granulocyte to lymphocyte ratio (GLR) were enumerated. GLR was used instead of NLR to keep all analysis based on flow cytometry measurements since some flow labs may not have hematological capability. A longitudinal compilation of the flow cytometric analyses and information obtained from the questionnaire completed at the time of each blood draw were assessed with respect to each study participant. Study subjects were mostly healthy volunteers with a few exceptions; none had been diagnosed with a cancer at the time of their analysis. 


\section{Materials and methods}

\section{Study group}

The individuals immunophenotyped for the lymphoid subsets were 133 females and 50 males, and for GLR, analyses were 90 females and 37 males. The total number of immunophenotyping analyses for lymphoid subsets was 806 , since many of the subjects were immunophenotyped multiple times. The subjects ranged in age from 19 to 84 years. The mean age of the donors was $45.2 \pm 9.6$ for females and $50.5 \pm 12.3$ for males. For females, $8.6 \%$ had an allergy, 5.7\% had a pathology, and $4.8 \%$ had high blood pressure. For males, $8.8 \%$ had an allergy, $11.1 \%$ had a pathology, and $4.4 \%$ had high blood pressure. The percentage of smokers was $14.4 \%$ for females and $11.1 \%$ for males. The blood was obtained by New York State Department of Health (NYSDOH) certified phlebotomists, and only staff working at NYSDOH were allowed to participate. All subjects provided written consent to participate in the NYSDOH IRB-approved project (Protocol \# 98-108). Many individuals were immunophenotyped three times per year, in January, May, and September. The age of each donor was recorded at the time of the analyses, which ranged from 1 to 23 times for an individual. Many subjects were immunophenotyped a total of 6 times and reported being healthy. Some consented donors did have an identified health problem.

\section{Blood collection and analysis}

Blood samples were collected between 9:15 and 11:30 $\mathrm{AM}$ in $\mathrm{K}_{2}$ EDTA BD Vacutainer ${ }^{\circledR}$ blood collection tubes and were immediately analyzed. Immunophenotyping for lymphoid cells was performed using the 4 or 6-color Multitest reagents from BD Biosciences (Palo Alto, CA). The whole blood was stained in $\mathrm{BD}$ Trucount ${ }^{\mathrm{TM}}$ tubes according to the manufacturer's protocol. Stained samples were run on BD FACSCalibur or FACSCanto instruments using MultiSet software or FACSCanto clinical software. Percentages for the minor T-cell subsets were obtained by importing the data files generated in MultiSet or FACSCanto clinical software into a template set-up using the CellQuest software or the FACSDiva software, respectively. Figure 1 shows dot plots demonstrating how the minor T-cell percentages were determined with the FACSDiva software. Instrument settings for voltage and compensation were held constant during the study. Sidescatter (SSC) vs CD45 plots were set-up in both the CellQuest and FACSDiva software, and a gate was made for the lymphocytes. The lymphocyte gate was applied to a plot of CD19 (B cells) vs CD3 (T cells) and CD56+CD16 vs CD3 to measure the NKT cells and CD16/CD56- $\mathrm{T}$ cells. The $\mathrm{CD}^{+} \mathrm{CD} 16 / \mathrm{CD}^{-} 6^{-}$plot was then applied to a plot for CD4 vs CD8 to obtain the percentages of the $\mathrm{CD} 4^{-} \mathrm{CD}^{-}{ }^{-}$(DN-) and $\mathrm{CD} 4^{+} \mathrm{CD} 8^{+}$(DP-) $\mathrm{T}$ cells and the $\mathrm{CD} 4^{+} \mathrm{CD} 8^{-}$vs $\mathrm{CD} 4^{-} \mathrm{CD} 8^{+} \mathrm{T}$ cells. Cell counts for the minor $\mathrm{T}$ cells were calculated from the counts for $\mathrm{T}$ cells generated by the clinical software using the Trucount tubes. Assays were performed by a single technician who underwent proficiency testing at least three times per year. Since our GLR calculation utilized the flow cytometric set gate for lymphocytes $\left(\mathrm{CD} 45^{\text {hi }} \mathrm{SSC}^{\text {low }}\right)$ and that for granulocytes (neutrophils $(\mathrm{N})+$ eosinophils, $\mathrm{CD} 45^{\text {low }} \mathrm{SSC}^{\text {hi }}$ ), the GLR values differ from reports by others for the NLR in that the lymphocyte gate may include a small percentage of monocytes and the granulocyte gate includes eosinophils. Basophils are not included in the granulocyte gate since they are $\mathrm{CD} 45^{\text {low }} \mathrm{SSC}^{\text {low }}$.

An inter-assay deviation test was performed to obtain the $\mathrm{CV} \%$ for the instrument and different preparations of the same sample. Both percentages and cell numbers $/ \mu \mathrm{L}$ were assessed. One blood sample was stained with the 4-color Multitest reagent 7 times and analyzed on the FACSCalibur flow cytometer. All standard deviations were less than 1 for the lymphocyte subset percentages, and all absolute counts had a CV\% $\leq 7$. The greatest accuracy was obtained with the absolute count for T cells having a CV\% of 3.1. Similar reproducibility was achieved with comparison of the same sample multiple times with 4 color FACSCalibur vs 6 color FACSCanto.

\section{Statistics}

All statistical analyses were performed using SigmaPlot 14.5. Means, ranges, standard deviation, and standard errors were calculated for each parameter. Statistical analyses were done using one-way to three-way ANOVA followed by Dunn's test to compare the results for age and sex; normality often failed so we ran ANOVA on ranks. Linear regression analysis was used to determine the relationship between age and lymphocyte frequency. Any $p$ value of $\leq 0.05$ was considered significant.

\section{Results}

\section{Analysis of variation over time for the lymphocyte subset counts}

Table 1 shows the mean values of the leukocyte subsets and their variances (CV\%) for females and males who were assayed 5-27 times for 2-12 years. Shown is the age range of the subjects during their participation in the study, and 

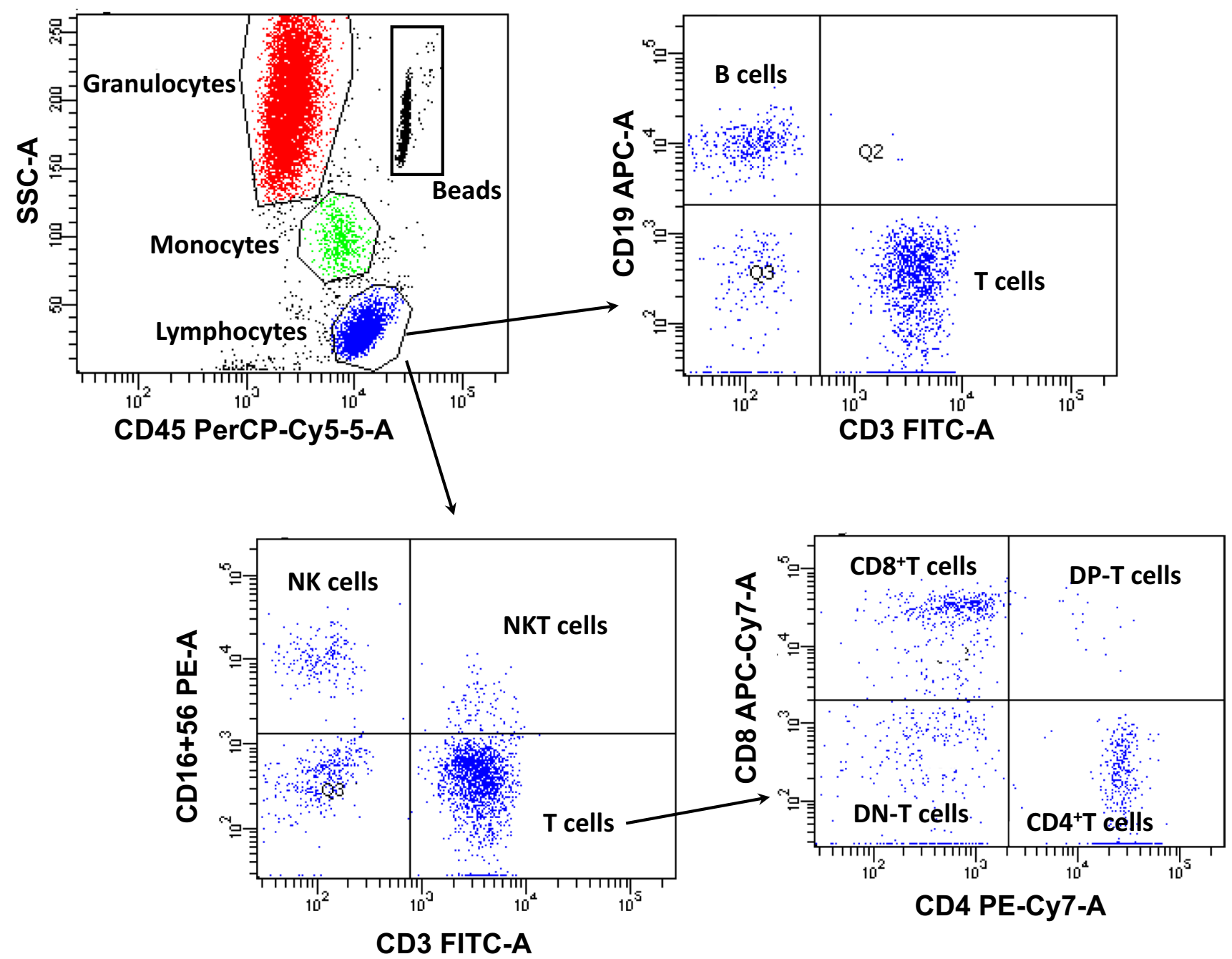

Fig. 1 Flow cytometric analysis scheme for the leukocyte percentages and absolute numbers

the number of times immunophenotyping was performed on each person. The results for many individuals indicated that there were some changes in the absolute count for each lymphocyte subset over time. In general, the cell number of each subset was somewhat consistent for many individuals. However, a few individuals did have substantial changes in some subsets, and the overall range of cell numbers for a lymphoid subset between individuals was quite wide, e.g., the $\mathrm{T}$ cell range was 369-3006 cells/ $\mu \mathrm{L}$ for females and 522-2693 cells $/ \mu \mathrm{L}$ for males. If only an individual's average was use, the range was less (461-2595 and 765-2275 for females and males, respectively), but the female range was still greater than that for males (Table 2). As mentioned, some individuals were assayed three times per year and for many years, and all values of each subset for all females and males were used to show median values with 10th, 25th, 75th, and 90th percentiles (Fig. 2). The two high values for $\mathrm{CD}^{+} \mathrm{T}$ cells $(2621,2549)$ were from the same female of 56 , who had disk surgery. The high number of B cells (2149, Fig. 2) was from a male of 60, and his B cell values were 934 and 1230 when he was 51 and 52. At 60, he also had the highest number of NKT cells (326/uL), and he was later diagnosed with leukemia. This male was not used for values shown in Table 3. For the gender comparison of lymphoid subsets (Table 3), we used the average of each subset from 104 females and 44 males; thus, the differences may be skewed since there were more females, and more females were assayed more often than males over more years. Although females tended to have slightly more DP-T cells and CD $4^{+} \mathrm{T}$ cells than males, males had significantly more NK cells than females. NKT cells were not quantified for subpopulations, but they were predominantly $\mathrm{CD}^{-}{ }^{-} \mathrm{CD} 8^{+}$and $\mathrm{CD} 4^{+} \mathrm{CD} 8^{+}$; the number of these NKT cell subpopulations was not subtracted from the $\mathrm{T}$ cell subpopulations, because as shown in Fig. 1, the $\mathrm{T}$ cell subpopulations were calculated from the $\mathrm{CD} 3{ }^{+} \mathrm{CD} 16 /$ $\mathrm{CD}^{-} 6^{-}$population. 


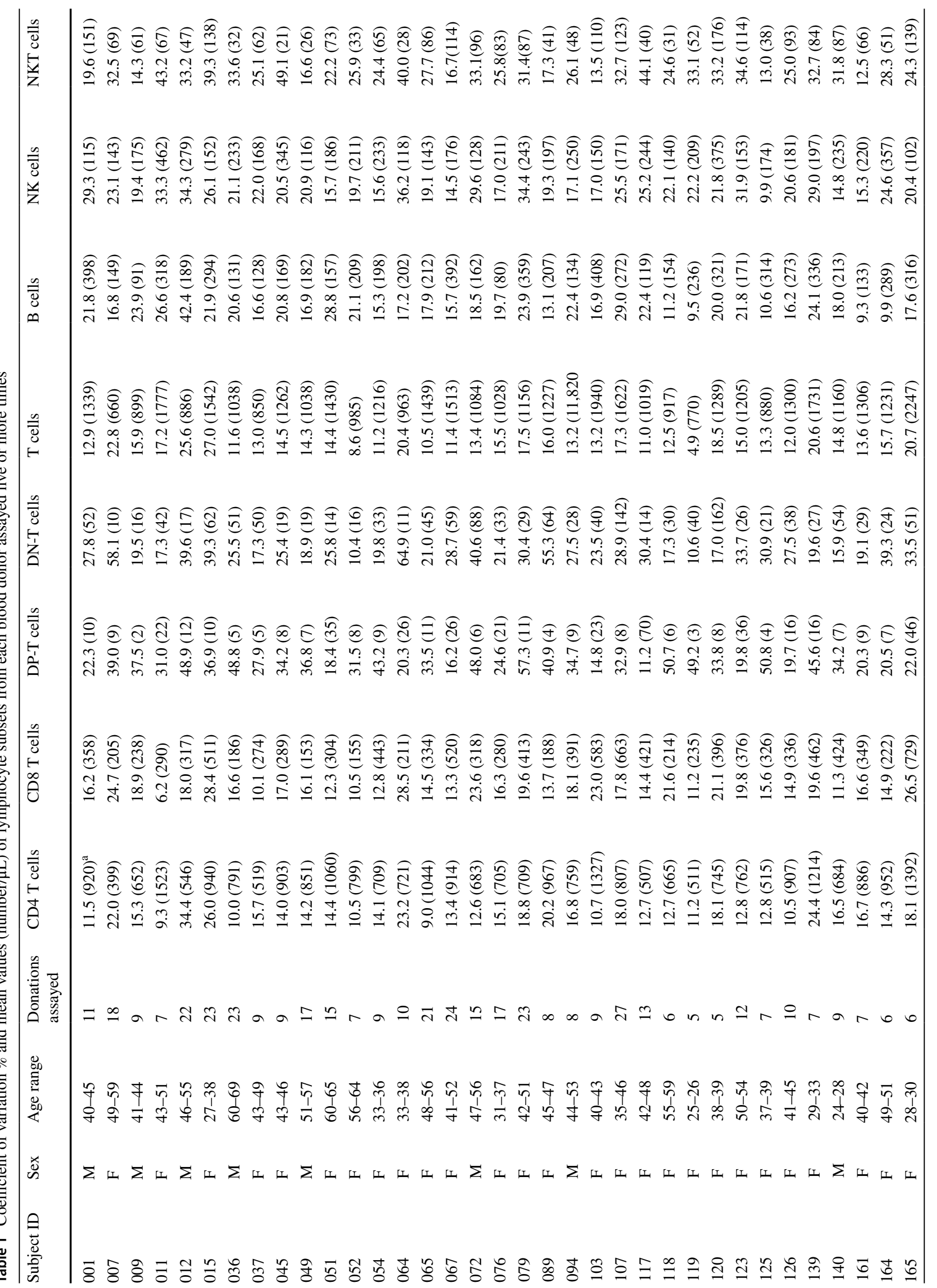


Table 2 Lymphoid subset of females and males (cell number/ $\mu \mathrm{L})^{a}$

\begin{tabular}{|c|c|c|}
\hline Lymphoid subset & Females $^{b}$ & $P_{\text {value }}{ }^{\mathrm{d}}$ \\
\hline \multirow[t]{2}{*}{$\mathrm{T}$ cells } & $1426.3 \pm 40.3^{e}$ & $1342.7 \pm 60.6 p=0.219$ \\
\hline & $461-2595$ & $765-2275$ \\
\hline \multirow[t]{2}{*}{$\mathrm{CD}^{+}{ }^{+} \mathrm{T}$ cells } & $938.3 \pm 29.3$ & $872.0 \pm 43.9 p=0.097$ \\
\hline & $323-2223$ & $482-1716$ \\
\hline \multirow[t]{2}{*}{$\mathrm{CD}^{+} \mathrm{T}$ cells } & $423.2 \pm 16.9$ & $401.9 \pm 28.7 p=0.347$ \\
\hline & $117-954$ & $100-1017$ \\
\hline \multirow[t]{2}{*}{ DP-T cells } & $22.3 \pm 3.1$ & $13.3 \pm 2.5 p=0.051$ \\
\hline & $2-192$ & $2-94$ \\
\hline \multirow[t]{2}{*}{ DN-T cells } & $40.6 \pm 2.9$ & $47.0 \pm 6.9 p=0.974$ \\
\hline & $4-161$ & $6-212$ \\
\hline \multirow[t]{2}{*}{$\mathrm{B}$ cells } & $266.1 \pm 13.5$ & $245.0 \pm 16.4 p=0.556$ \\
\hline & $80-777$ & $91-591$ \\
\hline \multirow[t]{2}{*}{ NK cells } & $231.4 \pm 10.8$ & $285.1 \pm 20.4 p=0.015$ \\
\hline & $63-838$ & $73-726$ \\
\hline \multirow[t]{2}{*}{ NKT cells } & $95.3 \pm 10.5$ & $96.0 \pm 12.0 p=0.854$ \\
\hline & $3-766$ & $13-283$ \\
\hline
\end{tabular}

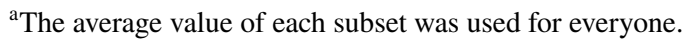

${ }^{\mathrm{b}}$ Females (age 45.2 \pm 0.4 mean $\pm \mathrm{SEM}$; range 22-68; $n=104$ ).

${ }^{\mathrm{c}}$ Males (age 50.5 $\pm 0.8 ; 24-84 ; n=44$ ).

${ }^{\mathrm{d}}$ Difference between females and males.

${ }^{\mathrm{e}} \mathrm{Mean} \pm \mathrm{SEM}$ and range for cell number $/ \mu \mathrm{L}$.

The ratio of $\mathrm{CD}^{+}{ }^{+}$to $\mathrm{CD} 8^{+} \mathrm{T}$ cells has been used to assess the immune condition since generally, a CD4/CD8 ratio of 1.5-2.5 has been considered normal [39]; thus, a CD4/CD8 ratio of $<1$ if repeatable might be grounds for potential concern. The results for our female and male participants are shown with median values with 10th, 25th, 75th, and 90th percentiles (Fig. 3). The CD4/CD8 T cell

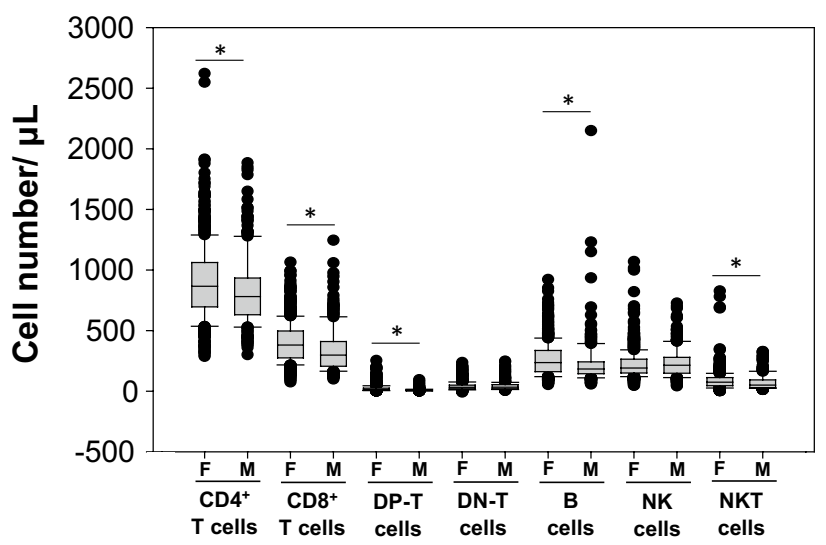

Fig. 2 All samples over 12 years were combined to assess variances in numbers of lymphoid subsets (cell number $/ \mu \mathrm{L}$ ) of females $(n=104)$ and males $(n=45)$. Analyses included 576 samples from the females and 230 samples from males. * Based on ANOVA on ranks and Dunn's test, the subsets of females significantly differed $(p<0.05)$ from those of males for all subsets except DN-T and NK cells 
Table 3 Variance of GLR values for individuals with six or more analysis

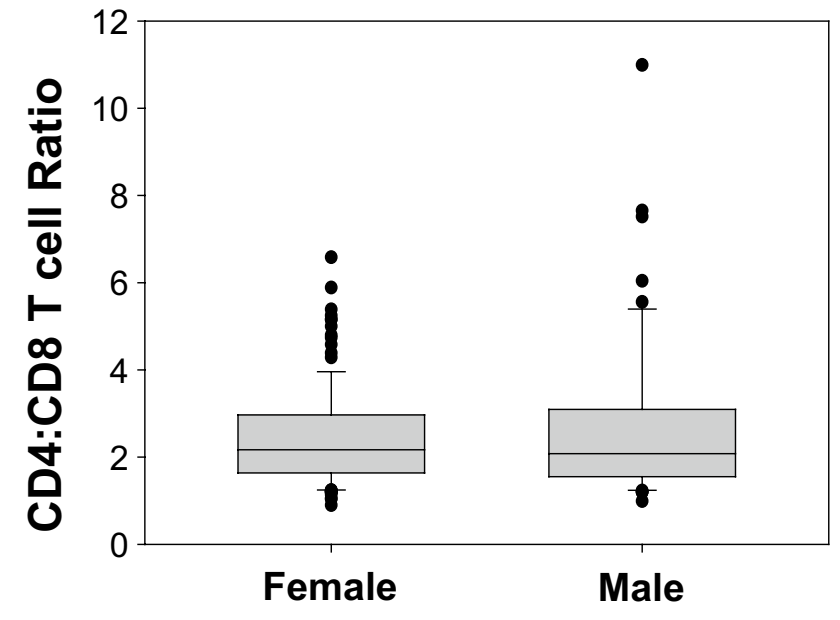

Fig. 3 The ratio of CD4 to CD8 T cells. The median and percentiles of CD4/CD8 are shown for females $(n=104)$ and males $(n=44)$. There was no significant difference

ratio was not significantly different between females and males. However, there was a broad range for females and males. The $\mathrm{CD} 4 / \mathrm{CD} 8$ ratios (mean \pm SEM and range) were $2.45 \pm 0.10$ and $0.89-6.58$ for females and $2.74 \pm 0.27$ and $0.99-10.99$ for males. The meaningfulness of a consistently high CD4/CD8 ratio is less clear; it may be indicative of a pathology.

\section{Leukocyte numbers based on age and gender}

With simple linear regression analysis of females and males using cell number/ $\mu \mathrm{L}$ blood for the granulocytes and lymphocytes subsets vs age, there were minimal differences between females and males; however, granulocyte numbers of females declined slightly more than those of males with age, and NK cell numbers of females and males slightly increased with age (not shown). DP-T cell numbers of females increased more than those of males with age, and $\mathrm{CD} 8^{+} \mathrm{T}$ cells and DN-T cells of females and males declined with age (Fig. 4). When the female and male results were combined, there were more subset differences based on age (Fig. 5). There was a slight but not significant $(p=0.0591)$ increase 

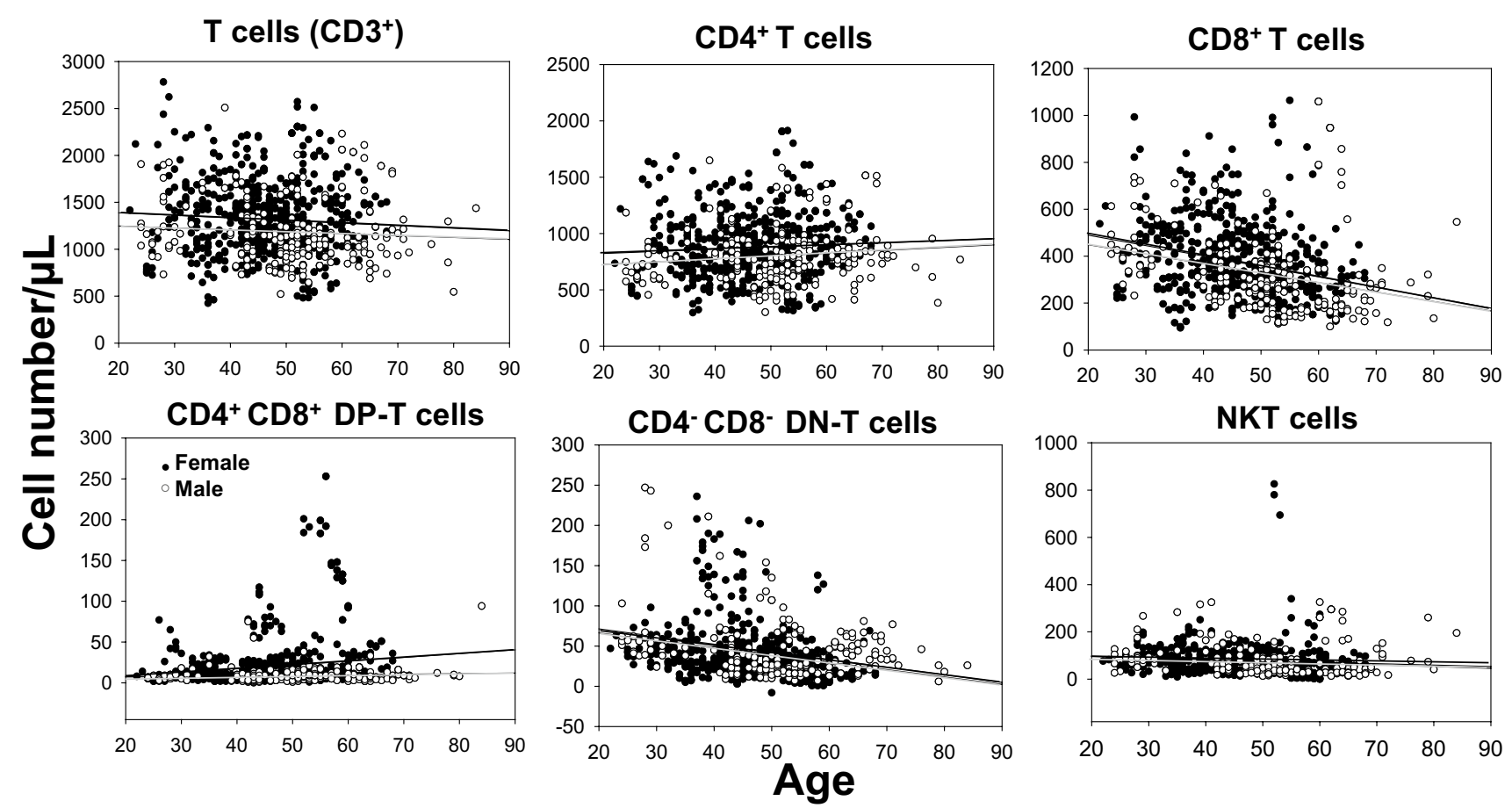

Fig. 4 Numbers of $\mathrm{T}$ cell subsets of females and males of various ages. The lymphoid subset cell numbers $/ \mu \mathrm{L}$ were based on immunophenotyped populations corrected for bead counts $/ \mu \mathrm{L}$. Results are shown for 104 females and 44 males. The linear regression line is shown for females (black) and males (gray)
Fig. 5 Numbers of lymphoid subsets combined for gender and assayed ages $18-80$. Combining female and male values at same age and exclusion of some outliers ( $>2$ SD from mean), some subsets decreased significantly $(p<0.05)$ with age *; whereas, DP-T cells increased significantly with age **. For $\mathrm{CD}^{+} \mathrm{T}$ cells and $\mathrm{NK}$ cells, there were no significant changes with age

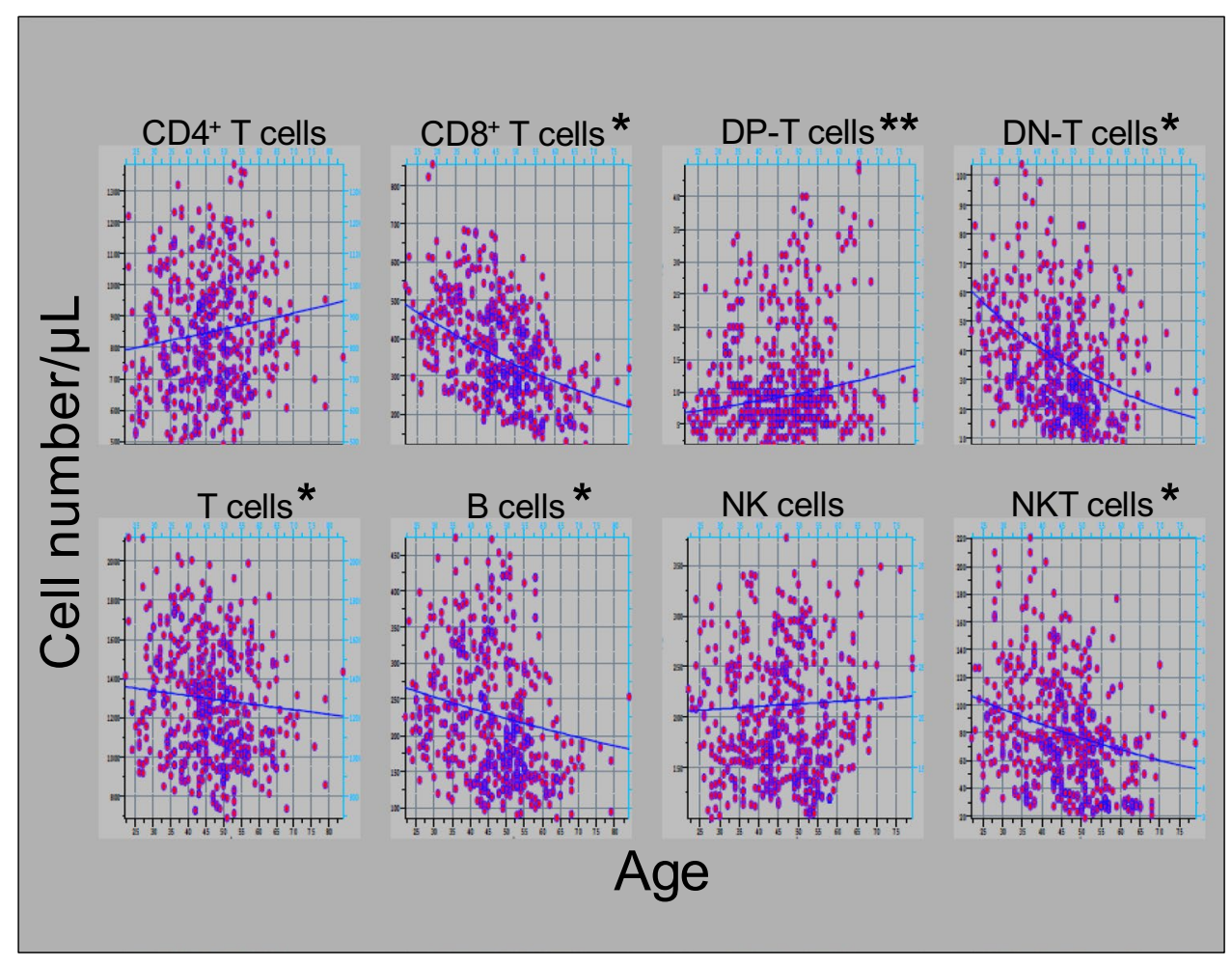


in $\mathrm{CD}^{+} \mathrm{T}$ cells, a significant $(p<0.001)$ decline in $\mathrm{CD}^{+} \mathrm{T}$ cells, a significant $(p<0.001)$ increase in DP-T cells, a significant $(p<0.001)$ decline in DN-T cells, a significant $(p=0.0326)$ decline in total T cells, a significant $(p<0.001)$ decline in B cells, and a significant $(p<0.001)$ decline in NKT cells; no significant change was obtained for NK cells.

\section{Seasonal influences on numbers of leukocyte subsets in blood of females and males}

Since many individuals were screened multiple times throughout the year and our proficiency program obtained samples in January, May, and September, we were able to assess whether blood subset numbers change throughout
Fig. 6 Seasonal changes in lymphoid subsets of females $(\mathrm{F})$ and males (M). Scatter plots and means are shown for $\mathrm{CD} 4^{+} \mathrm{T}$ cells, CD8 ${ }^{+} \mathrm{T}$ cells, B cells, NK cells, DP-T cells, DN-T cells, total T cells, and NKT cells. The solid line shows the means for the females and males for each subpopulation in each season, and the dashed line shows that the female subpopulation means decline in September and cellular subset numbers for males are lower than those of females except for NK cells
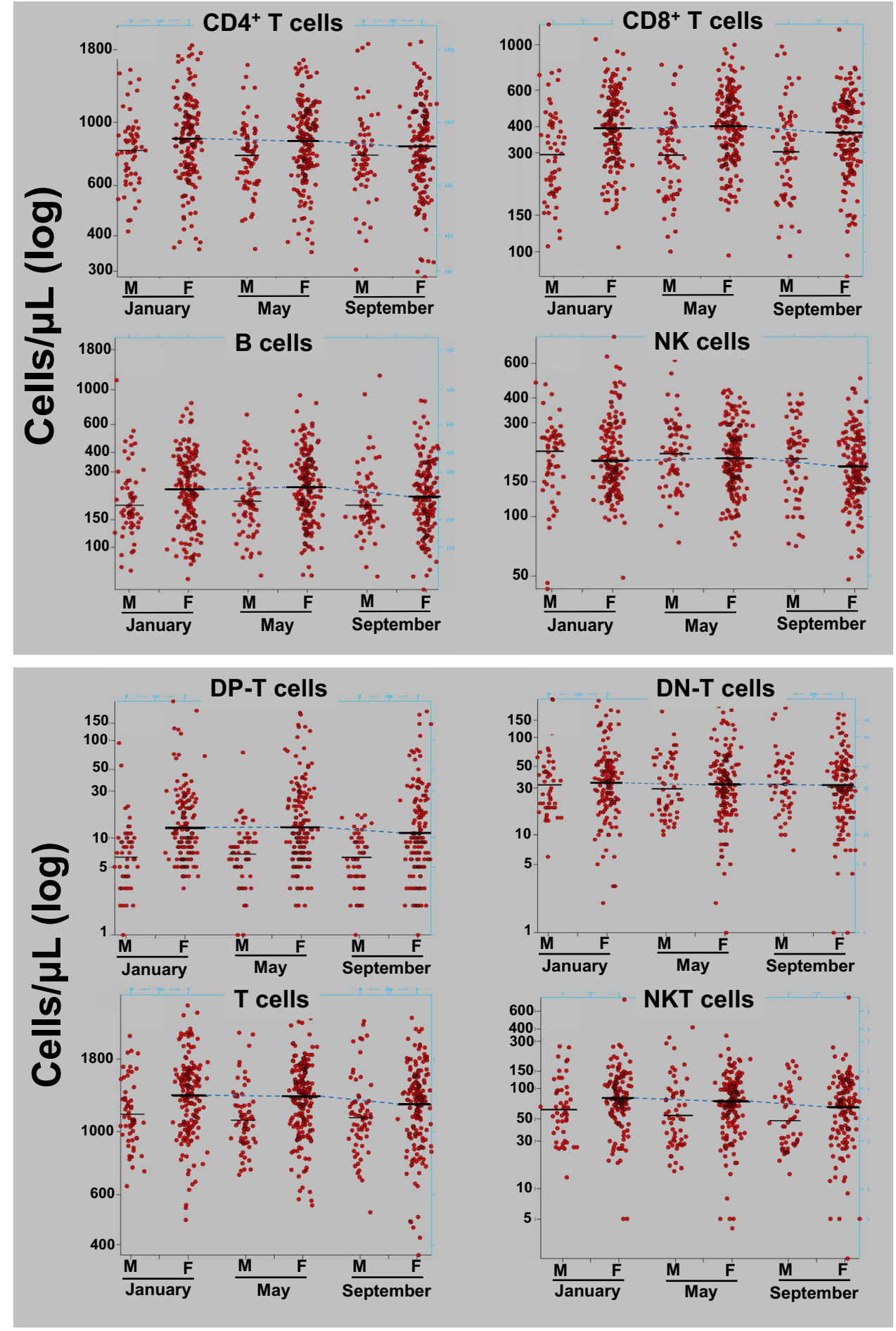
the year (Fig. 6). For $\mathrm{CD} 4^{+} \mathrm{T}$ cells, $\mathrm{CD} 8^{+} \mathrm{T}$ cells, B cells, DP-T cells, total T cells, and NKT cells, the cell numbers for males were consistently lower than those for females in all seasons, which is consistent with the results shown in previous figures. There were no differences between females and males for NK cells and DN-T cells regardless of season although the mean for the NK cell numbers of males are slightly higher in all seasons than those of the females. Additionally, there was a slight decline of all subsets for females in September.

\section{GLR values based on age and gender}

The GLR for females, but not males, declined slightly with age, and more females had GLR values $>3$ than males (Fig. 7). The median and percentiles for the GLR values are shown (Fig. 8), as described for CD4/CD8 ratio (Fig. 3). The mean \pm SEM and range for the GLR data for females and males were $1.99 \pm 0.05$ and $0.72-5.96$ and $2.05 \pm 0.07$ and $0.90-4.54$, respectively. The GLR values did not significantly differ based on gender, but as indicated in Fig. 8, more GLR values of females were above 3. A few variations of GLR for some individuals at different times are shown (Fig. 9). An individual's GLR value may temporarily increase (male ID36) due to a stress or gradually increase as for male ID48, who was later diagnosed with cancer. Male ID1 had some musculoskeletal problems starting at 44. Female ID7 has allergies. ID9 had depression at age 44 and hypertension at 45. Male ID49 had fibroplasia. ID64 has asthma. ID12, ID15, and ID36 reported no health problems. Although there were no significant gender differences in GLR values (Table 3), the females did tend to display more variation. A female (ID126) in age range of 41-45 with no reported health concerns had values of 1.24, 4.73, 2.47, 1.89, 3.68 , and 1.90. These sporadic increases $>3$ might suggest a temporary stress event.

Since to obtain the GLR we used the total lymphocyte number and the total neutrophil number based on flow

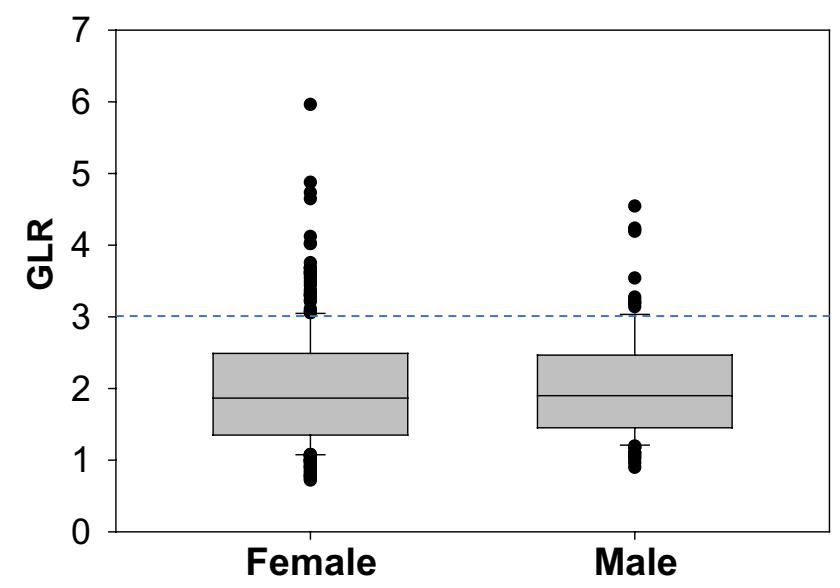

Fig. 8 Total range of GLR values for females and males. The median and percentiles of the GLR values are shown for females and males. There was no significant difference

cytometric gates that may include low percentages of monocytes and eosinophils, respectively, we also did regression plots and linear regression analysis of $\mathrm{CD}^{+} \mathrm{T}$ cells or $\mathrm{CD} 8^{+}$ $\mathrm{T}$ cells with the GLR values for females and males. All that could be concluded is that there are no significant differences if GLR is correlated with $\mathrm{CD} 4^{+}$or $\mathrm{CD} 8^{+} \mathrm{T}$ cells.

\section{Discussion}

The CDC designates that an acceptable variation in the percentage of $\mathrm{T}$ cell subsets to be $3 \%$ for inter-laboratory and inter-methodology variation in the reporting of results for a control stabilized blood sample [40]. Most consistent and accurate results were obtained using the heterogeneous gating system for lymphocytes of CD45 vs side scatter [41-43]. Further, a switch from dual-platform to a singleplatform method for determining absolute cell counts also decreased $\mathrm{CV} \%$ in interlaboratory reporting of test results
Fig. 7 Granulocyte to lymphocyte ratio (GLR) of females and males based on age. There were no significant changes with age

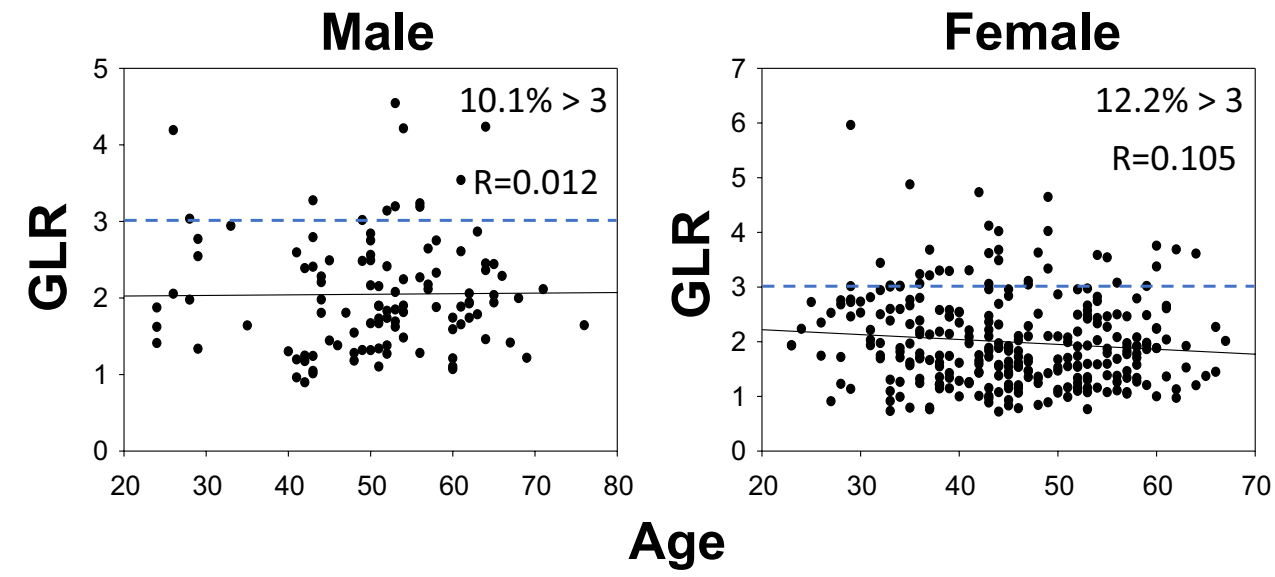



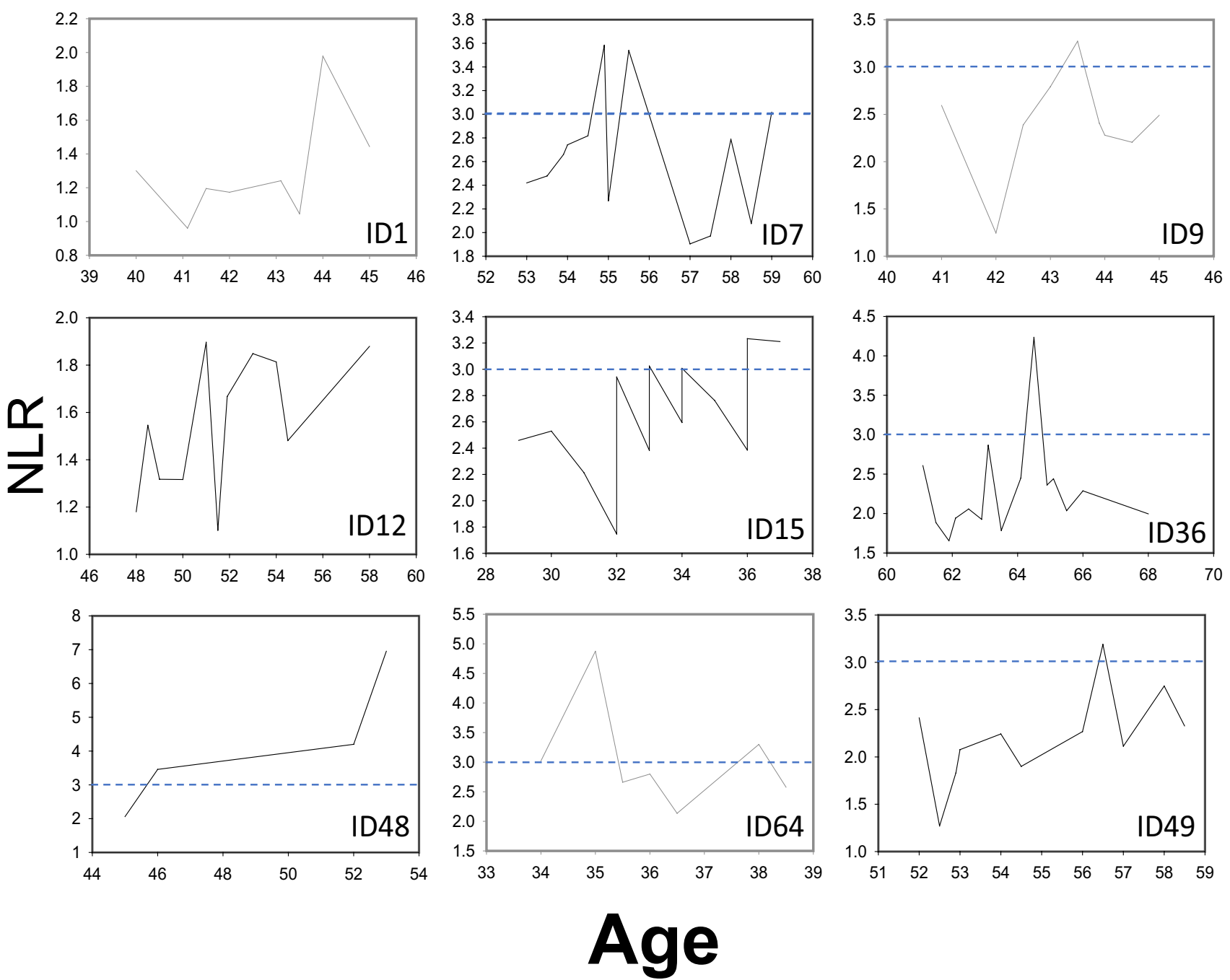

Fig. 9 Individual GLR variances. Fluctuations in GLR values with age from females (ID7, ID15, ID64) and males (ID1, ID9, ID12, ID36, ID48, ID49)

[40, 41]. For this longitudinal study, 3, 4, and 6 colors with single-platform methodology were employed to obtain the results. Single sample replicate assays provided percentages and count variations well within guidelines set by the CDC. Attempts were made to follow all quality control measures during the study.

Our longitudinal study, over the 14-year period, lead to several noteworthy outcomes. Females presented the greatest seasonal variation. Cell numbers for most subsets went down from means in May to those in September. The number of blood leukocyte populations has been reported to vary by season and location [44], but lymphocyte subsets were not assayed. The incidence and disease activity of cardiovascular disease [45] and autoimmune disease [46, 47] in humans has also been suggested to have seasonality. Since our study population covered a wide range of ages and we followed many of the study subjects over a relatively long period of time, we were able to examine the lymphocyte population during aging. We found that $\mathrm{CD} 4^{+} \mathrm{T}$ cells slightly increased and DP-T cells significantly increased with age, but $\mathrm{CD} 8^{+}$ T-cells, DN-T cells, B cells, and NKT-cells decreased with age. The decrease in $\mathrm{CD} 8^{+} \mathrm{T}$ cell numbers with increased age agrees with previous reports [48-50]. Changes in the number of lymphocytes between winter and summer have been suggested to be connected to the number of hours of day light hours between the two seasons. The shorter day lengths in winter lead to increased numbers of $\mathrm{T}$ and $\mathrm{B}$ cells $[51,52]$. Previous reports for seasonal variation of NK cells were performed on a population of school children. Here, we show seasonal variation of the NK cells in male and female adults. NK cells were the only lymphocyte population that had a higher means for males than for females, and the NK cell means for males also dropped from the means in January to those in September. 
One of the minor lymphocyte subsets examined in this study was the DP-T cells. Although this is a minor population in humans, it is a relatively large population in swine, chickens, and monkeys. Therefore, much of the knowledge acquired about DP-T cells has been obtained in these species. It has been suggested that extrathymic DP-T cells do not originate from the thymus but are developed from either $\mathrm{CD}^{+}$or $\mathrm{CD}^{+} \mathrm{T}$ cells in the periphery $[53,54]$. These DP-T cells appear to be a population of memory cells in that they usually are MHC class II positive, express memory cell markers, and produce interferon- $\gamma$ [53]. Other studies also indicated that the DP-T cells were a population of activated, phenotypically distinct, and primed $\mathrm{T}$ cells $[55,56]$. In studies of cynomolous monkeys, it was reported that peripheral blood DP-T cells were of a resting $\mathrm{T}$ cell memory lineage and increased in number with age [57]. Increased numbers of DP-T cells in humans during aging has also been observed [56, 58]. Our results are in agreement with these findings in that our data suggests expansion of the DP-T lymphocyte subset population with age.

Previous reports concerning DN-T cells in humans were given a range of $0-2 \%$ for the normal population, but our data suggests that the normal population may have a range somewhat broader. Strong interest in the DN-T population was triggered by the finding that patients with autoimmune lymphoproliferative syndrome (ALPS) have significantly higher percentages and absolute numbers of DN-T cells, bearing either $\alpha / \beta$ or $\gamma / \delta$ TCRs, than the control population [59-62]. Examination of the DN-T cells found in ALPS patients revealed that some of these cells contain somatic mutations in the Fas gene. These mutations can be found in a variety of forms depending on the patient, but in ALPS patients, all can effectively block apoptosis of the DN-T cells [61]. Mutations have also been detected in the Caspase 10 gene, which would also lead to a block of apoptosis [63]. Therefore, it was proposed that the DN-T cells are generated from a SP-T cell being given a death signal but being unable to die due to some inability to undergo apoptosis. In ALPS patients, the DN-T population can reach as high as $40 \%$ of the lymphocyte population. The disease is also characterized by hypergammaglobulinemia and autoimmune manifestations. Association with autoimmunity was also observed in patients with systemic lupus erythematosus (SLE) where it was noted that DN-T cells provided help to B cells expressing CD1c, resulting in production of autoantibodies (IgGs) [64]. In SLE, the DN-T cells differed from those from healthy controls in that they expressed IL-4 in addition to the IFN- $\gamma$ normally expressed by DN-T cells. A decrease in the number of the DN-T cells during aging was suggested by the ALPS studies [62]. Here, we present data indicating that DN-T cells markedly decrease with aging in the healthy control human population. Additionally, there were no gender, or seasonal, differences observed for this sub-population in our study.

Unlike DP-T and DN-T cells, NKT cells follow a unique pathway of differentiation in the thymus which breaks from that of conventional thymocyte development at the double-positive stage $[65,66]$. NKT cells in humans express either the V $\alpha 24-\mathrm{J} \alpha 18$ or the $\mathrm{V} \alpha \mathrm{7}-\mathrm{J} \alpha 33$ arrangement of TCRs that recognize the non-polymorphic class I molecules CD1d or MR1, respectively. For this reason, the NKT cells can respond to glycolipid antigens, such as galactosylceramide [67-69]. Activation of the NKT cells by presentation of the glycolipid can enhance B cell responses to protein antigens. This means the NKT cells can behave like helper cells to increase B cell proliferation and increase immunoglobulin production. Further, the activated NKT cells are associated with maintenance of B-cell memory and recall responses. Unfortunately, NKT cells' exuberance in combating microbial disease infections also leads to secretion of many proinflammatory cytokines, which can promote the initiation of autoimmune inflammation reactions [70, 71]. NKT cells try to regulate their cytokine expression after sensing the presence of IL-2 and a ubiquitous endogenous ligand. Our study indicated that the number of NKT cells decreased in humans during aging; this decrease might contribute to a weakening of the immune system regarding fighting off pathogens in the elderly.

The GLR results obtained by analysis of the flow data indicated that the GLR can be affected by a wide variety of circumstances. Several of the healthy donors with relatively low GLR values would at times show a spike in their GLR. This jump in the GLR, sometimes as high as $>4$, could be due to a pathogen infection or other momentary stress. It has been reported that certain forms of stress can increase peripheral blood neutrophils and decrease the lymphocyte count [28]. Also, the donor with RA had chronically low lymphocyte counts, which elevated the GLR to $>4$ for each time the person was screened. For several of the subjects in the study, a gradual increase in the GLR was observed over time. It could be possible that these individuals developed serious health problems after the study ended, but no follow-up was able to be performed to obtain this information. Considering the present study results, it would be important to combine the GLR value with other markers for inflammation to get a more accurate assessment of a patient's condition. To be more consistent with other reports using NLR instead of GLR, inclusion of neutrophil vs eosinophil percentages of the granulocyte population might further aid patient analysis with use of CD49d. It would be best to follow the patient over a period to be sure that the elevated GLR was not caused by some momentary stress event. 
Acknowledgements The authors thank Dr. Andrew Reilly of Wadsworth Center's Biostatistics Core for his assistance with some of the results.

\section{Declarations}

Conflict of interest The authors declare that they have no conflict of interest.

\section{References}

1. Maes M, Van Bockstaele DR, Gastel A, Song C, Schotte C, Neels H, DeMeester I, Scharpe S, Janca A. The effects of psychological stress on leukocyte subset distribution in humans: evidence of immune activation. Neuropsychobiology. 1999;39(1):1-9. https:// doi.org/10.1159/000026552.

2. Dhabhar FS, Malarkey WB, Neri E, McEwen BS. Stress-induced redistribution of immune cells-from barracks to boulevards to battlefields: a tale of three hormones-Curt Richter Award winner. Psychoneuroendocrinology. 2012;37(9):1345-68. https://doi.org/ 10.1016/j.psyneuen.2012.05.008.

3. Kasten-Jolly J, Lawrence DA. The minor T cell subsets in blood may not be minor in helping to assess human health. J Immunol Forecast. 2019;2(1):1007.

4. Pinti M, Appay V, Campisi J, Frasca D, Fülöp T, Sauce D, Larbi A, Weinberger B, Cossarizza A. Aging of the immune system: focus on inflammation and vaccination. Eur J Immunol. 2016;46(10):2286-301

5. Falandry C, Gilson E, Rudolph KL. Are aging biomarkers clinically relevant in oncogeriatrics? Crit Rev Oncol Hematol. 2013;85(3):257-65. https://doi.org/10.1016/j.critrevonc.2012.08. 004 .

6. Fülöp T, Larbi A, Witkowski JM. Human inflammaging. Gerontology. 2019;65(5):495-504. https://doi.org/10.1159/000497375.

7. Valiathan R, Ashman M, Asthana D. Effects of ageing on the Immune system: infants to elderly. Scand J Immunol. 2016;83(4):255-66. https://doi.org/10.1111/sji.12413.

8. Pawelec G. Immunosenescence and cancer. Biogerontology. 2017;18(4):717-21. https://doi.org/10.1007/s10522-017-9682-z.

9. Bektas A, Schurman SH, Sen R, Ferrucci L. Human T cell immunosenescence and inflammation in aging. J Leukoc Biol. 2017;102(4):977-88. https://doi.org/10.1189/jlb.3RI0716-335R.

10. Rea IM, Gibson DS, McGilligan V, McNerlan SE, Alexander HD, Ross OA. Age and age-related diseases: role of inflammation triggers and cytokines. Front Immunol. 2018;9:586. https://doi.org/ 10.3389/fimmu.2018.00586.

11. Balkwill F, Mantovani A. Inflammation and cancer: back to Virchow? Lancet. 2001;357(9255):539-45. https://doi.org/10.1016/ S0140-6736(00)04046-0.

12. Nikoo MH, Taghavian SR, Golmoghaddam H, Arandi N, Abdi Ardakani A, Doroudchi M. Increased IL-17A in atrial fibrillation correlates with neutrophil to lymphocyte ratio. Iran J Immunol. 2014;11(4):246-58.

13. García LF. Immune response, inflammation, and the clinical spectrum of COVID-19. Front Immunol. 2020;11:1441. https://doi. org/10.3389/fimmu.2020.01441.

14. Li X, Liu Y, Li J, Sun L, Yang J, Xu F, Zhou J, Wan L, Xu X, Le A, Zhang W. Immune characteristics distinguish patients with severe disease associated with SARS-CoV-2. Immunol Res. 2020;68(6):398-404. https://doi.org/10.1007/ s12026-020-09156-2.

15. Afari ME, Bhat T. Neutrophil to lymphocyte ratio (NLR) and cardiovascular diseases: an update. Expert Rev Cardiovasc Ther.
2016;14(5):573-7. https://doi.org/10.1586/14779072.2016.11547 88.

16. Sacdalan DB, Lucero JA, Sacdalan DL. Prognostic utility of baseline neutrophil-to-lymphocyte ratio in patients receiving immune checkpoint inhibitors: a review and meta-analysis. Onco Targets Ther. 2018;11:955-65. https://doi.org/10.2147/OTT.S153290.

17. Gibson PH, Cuthbertson BH, Croal BL, Rae D, El-Shafei H, Gibson G, Jeffrey RR, Buchan KG, Hillis GS. Usefulness of neutrophil/lymphocyte ratio as predictor of new-onset atrial fibrillation after coronary artery bypass grafting. Am J Cardiol. 2010;105(2):186-91.

18. Arbel Y, Finkelstein A, Halkin A, et al. Neutrophil/lymphocyte ratio is related to the severity of coronary artery disease and clinical outcome in patients undergoing angiography. Atherosclerosis. 2012;225(2):456-60. https://doi.org/10.1016/j.atherosclerosis. 2012.09.009.

19. Ertaş G, Sönmez O, Turfan M, Kul S, Erdoğan E, Tasal A, Bacaksiz A, Vatankulu MA, Altıntaş O, Uyarel H, Göktekin O. Neutrophil/lymphocyte ratio is associated with thromboembolic stroke in patients with non-valvular atrial fibrillation. J Neurol Sci. 2013;324(1-2):49-52.

20. Tokgoz S, Kayrak M, Akpinar Z, Seyithanoğlu A, Güney F, Yürüten B. Neutrophil lymphocyte ratio as a predictor of stroke. J Stroke Cerebrovasc Dis. 2013;22(7):1169-74.

21. Paquissi FC. The role of inflammation in cardiovascular diseases: the predictive value of neutrophil-lymphocyte ratio as a marker in peripheral arterial disease. Ther Clin Risk Manag. 2016;12:85160. https://doi.org/10.2147/TCRM.S107635.

22. Kulaksizoglu B, Kulaksizoglu S. Relationship between neutrophil/lymphocyte ratio with oxidative stress and psychopathology in patients with schizophrenia. Neuropsychiatr Dis Treat. 2016;12:1999-2005. https://doi.org/10.2147/NDT.S110484.

23. Ethier JL, Desautels D, Templeton A, Shah PS, Amir E. Prognostic role of neutrophil-to-lymphocyte ratio in breast cancer: a systematic review and meta-analysis. Breast Cancer Res. 2017;19(1):2. https://doi.org/10.1186/s13058-016-0794-1.

24. Diem S, Schmid S, Krapf M, Flatz L, Born D, Jochum W, Templeton AJ, Früh M. Neutrophil-to-lymphocyte ratio (NLR) and platelet-to-lymphocyte ratio (PLR) as prognostic markers in patients with non-small cell lung cancer (NSCLC) treated with nivolumab. Lung Cancer. 2017;111:176-81. https://doi.org/10. 1016/j.lungcan.2017.07.024.

25. Miyamoto R, Inagawa S, Sano N, Tadano S, Adachi S, Yamamoto M. The neutrophil-to-lymphocyte ratio (NLR) predicts short-term and long-term outcomes in gastric cancer patients. Eur J Surg Oncol. 2018;44(5):607-12. https://doi.org/10.1016/j.ejso.2018. 02.003 .

26. Asaoka T, Miyamoto A, Maeda S, Tsujie M, Hama N, Yamamoto K, Miyake M, Haraguchi N, Nishikawa K, Hirao M, Ikeda M, Sekimoto M, Nakamori S. Prognostic impact of preoperative NLR and CA19-9 in pancreatic cancer. Pancreatology. 2016;16(3):43440. https://doi.org/10.1016/j.pan.2015.10.006.

27. Marchioni M, Primiceri G, Ingrosso M, Filograna R, Castellan $P$, De Francesco P, Schips L. The clinical use of the neutrophil to lymphocyte ratio (NLR) in urothelial cancer: a systematic review. Clin Genitourin Cancer. 2016;14(6):473-84. https://doi.org/10. 1016/j.clgc.2016.04.008.

28. Zieziulewicz TJ, Mondal TK, Gao D, Lawrence DA. Stressinduced effects, which inhibit host defenses, alter leukocyte trafficking. Cell Stress Chaperones. 2013;18(3):279-91. https://doi. org/10.1007/s12192-012-0380-0.

29. Swan MP, Hickman DL. Evaluation of the neutrophil-lymphocyte ratio as a measure of distress in rats. Lab Anim. 2014;43:276-82.

30. Lecot P, Sarabi M, Pereira Abrantes M, Mussard J, Koenderman L, Caux C, Bendriss-Vermare N, Michallet MC. Neutrophil heterogeneity in cancer: from biology to therapies. Front Immunol. 
2019;10:2155. https://doi.org/10.3389/fimmu.2019.02155.eColl ection2019.

31. Iwata M, Ota KT, Li XY, Sakaue F, Li N, Dutheil S, Banasr M, Duric V, Yamanashi T, Kaneko K, Rasmussen K, Glasebrook A, Koester A, Song D, Jones KA, Zorn S, Smagin G, Duman RS. Psychological stress activates the inflammasome via release of adenosine triphosphate and stimulation of the purinergic type $2 \mathrm{X} 7$ receptor. Biol Psychiatry. 2016;80(1):12-22. https://doi.org/10. 1016/j.biopsych.2015.11.026.

32. Nishitani N, Sakakibara H. Association of psychological stress response of fatigue with white blood cell count in male daytime workers. Ind Health. 2014;52(6):531-4. https://doi.org/10.2486/ indhealth.2013-0045.

33. Gudenkauf LM, Ehlers SL. Psychosocial interventions in breast cancer survivorship care. Breast. 2018;38:1-6. https://doi.org/10. 1016/j.breast.2017.11.005.

34. Haram A, Boland MR, Kelly ME, Bolger JC, Waldron RM, Kerin MJ. The prognostic value of neutrophil-to-lymphocyte ratio in colorectal cancer: a systematic review. J Surg Oncol. 2017;115(4):470-9. https://doi.org/10.1002/jso.24523.

35. Bowen RC, Little NAB, Harmer JR, Ma J, Mirabelli LG, Roller KD, Breivik AM, Signor E, Miller AB, Khong HT. Neutrophilto-lymphocyte ratio as prognostic indicator in gastrointestinal cancers: a systematic review and meta-analysis. Oncotarget. 2017;8(19):32171-89. https://doi.org/10.18632/oncotarget.16291.

36. Guo G, Chen X, He W, Wang H, Wang Y, Hu P, Rong Y, Fan L, Xia L. Establishment of inflammation biomarkers-based nomograms to predict prognosis of advanced colorectal cancer patients based on real world data. PLoS ONE. 2018;13(12):e0208547. https://doi.org/10.1371/journal.pone.0208547.

37. Sunbul EA, Sunbul M, Yanartas O, Cengiz F, Bozbay M, Sari I, Gulec H. Increased neutrophil/lymphocyte ratio in patients with depression is correlated with the severity of depression and cardiovascular risk factors. Psychiatry Investig. 2016;13(1):121-6. https://doi.org/10.4306/pi.2016.13.1.121.

38. Demir S, Atli A, Bulut M, İbiloğlu AO, Güneş M, Kaya MC, Demirpençe Ö, Sır A. Neutrophil-lymphocyte ratio in patients with major depressive disorder undergoing no pharmacological therapy. Neuropsychiatr Dis Treat. 2015;11:2253-8. https://doi. org/10.2147/NDT.S89470.

39. McBride JA, Striker R. Imbalance in the game of T cells: what can the CD4/CD8 T-cell ratio tell us about HIV and health? PLos Pathog. 2017;13(1):e1006624. https://doi.org/10.1371/journal. ppat.1006624.

40. Mandy F, Bergeron M, Houle G, Bradley J, Fahey J. Impact of the international program for quality assessment and standardization for immunological measures relevant to HIV/AIDS: QASI. Cytometry. 2002;50(2):111-6. https://doi.org/10.1002/cyto. 10088.

41. Gratama JW, Kraan J, Keeney M, Granger V, Barnett D. Reduction of variation in T-cell subset enumeration among 55 laboratories using single-platform, three or four-color flow cytometry based on CD45 and SSC-based gating of lymphocytes. Cytometry. 2002;50(2):92-101. https://doi.org/10.1002/cyto.10084.

42. Schnizlein-Bick CT, Mandy FF, O'Gorman MRG, Paxton H, Nicholson JKA, Hultin LE, Gelman RS, Wilkening CL, Livnat D. Use of CD45 gating in three and four-color flow cytometric immunophenotyping: guideline from the National Institute of Allergy and Infectious Diseases. Division AIDS Cytomtery. 2002;50(2):46-52. https://doi.org/10.1002/cyto.10073.

43. Illoh OC. Current applications of flow cytometry in the diagnosis of primary immunodeficiency diseases. Arch Pathol Lab Med. 2004;128(1):23-31. https://doi.org/10.1043/1543-2165(2004) 128\%3c23:CAOFCI\%3e2.0.CO;2.

44. Dopico XC, Evangelou M, Ferreira RC, Guo H, Pekalski ML, Smyth DJ, Cooper N, Burren OS, Fulford AJ, Hennig BJ, Prentice
AM, Ziegler AG, Bonifacio E, Wallace C, Todd JA. Widespread seasonal gene expression reveals annual differences in human immunity and physiology. Nat Commun. 2015;6:7000. https:// doi.org/10.1038/ncomms8000.

45. Pell JP. Cobbe SM Seasonal variations in coronary heart disease. QJM. 1999;92:689-96.

46. Iikuni N, Nakajima A, Inoue E, Tanaka E, Okamoto H, Hara M, Tomatsu T, Kamatani N, Yamanaka H. What's in season for rheumatoid arthritis patients? Seasonal fluctuations in disease activity. Rheumatology (Oxford). 2007;46(5):846-8. https://doi.org/ 10.1093/rheumatology/kel414.

47. Moltchanova EV, Schreier N, Lammi N, Karvonen M. Seasonal variation of diagnosis of type 1 diabetes mellitus in children worldwide. Diabet Med. 2009;26:673-8.

48. Goronzy JJ, Lee WW, Weyand CM. Aging and T-cell diversity. Exp Gerontol. 2007;42(5):400-6. https://doi.org/10.1016/j.exger. 2006.11.016.

49. Gupta S, Gollapudi S. CD95-mediated apoptosis in naïve, central and effector memory subsets of CD4+ and CD8+ T cells in aged humans. Exp Gerontol. 2008;43(4):266-74. https://doi.org/10. 1016/j.exger.2007.12.006.

50. Sansoni P, Vescovini R, Fagnoni F, Biasini C, Zanni F, Zanlari L, Telera A, Lucchini G, Passeri G, Monti D, Franceschi C, Passeri M. The immune system in extreme longevity. Exp Gerontol. 2008;43(2):61-5. https://doi.org/10.1016/j.exger.2007.06.008.

51. Paglieroni TG, Holland PV. Circannual variation in lymphocyte subsets, revisited. Transfusion. 1994;34(6):512-6. https://doi.org/ 10.1046/j.1537-2995.1994.34694295067.x.

52. Prendergast BJ, Kampf-Lassin A, Yee JR, Galang J, McMaster N, Kay LM. Winter day lengths enhance T lymphocyte phenotypes, inhibit cytokine responses, and attenuate behavioral symptoms of infection in laboratory rats. Brain Behav Immun. 2007;21(8):1096-108. https://doi.org/10.1016/j.bbi.2007.05.004.

53. Zuckermann FA. Extrathymic CD4/CD8 double positive T cells. Vet Immunol Immunopathol. 1999;72(1-2):55-66. https://doi.org/ 10.1016/s0165-2427(99)00118-x.

54. Overgaard NH, Jung JW, Steptoe RJ, Wells JW. CD4+/CD8+ double-positive T cells: more than just a developmental stage? J Leukoc Biol. 2015;97:31-8.

55. Kenny E, Mason D, Pombo A, Ramírez F. Phenotypic analysis of peripheral CD4+ CD8+ T cells in the rat. Immunology. 2000;101(2):178-84. https://doi.org/10.1046/j.1365-2567.2000. 00071.x.

56. Laux I, Khoshnan A, Tindell C, Bae D, Zhu X, June CH, Effros RB, Nel A. Response differences between human CD4(+) and CD8(+) T-cells during CD28 costimulation: implications for immune cell-based therapies and studies related to the expansion of double-positive T-cells during aging. Clin Immunol. 2000;96(3):187-97. https://doi.org/10.1006/clim.2000.4902.

57. Akari H, Terao K, Murayama Y, Nam KH, Yoshikawa Y. Peripheral blood CD4+CD8+ lymphocytes in cynomolgus monkeys are of resting memory T lineage. Int Immunol. 1997;9(4):591-7. https://doi.org/10.1093/intimm/9.4.591.

58. Ghia P, Prato G, Stella S, Scielzo C, Geuna M, Caligaris-Cappio F. Age-dependent accumulation of monoclonal CD4+CD8+ double positive $\mathrm{T}$ lymphocytes in the peripheral blood of the elderly. $\mathrm{Br}$ J Haematol. 2007;139(5):780-90. https://doi.org/10.1111/j.13652141.2007.06867.x.

59. Bleesing JJ, Brown MR, Straus SE, Dale JK, Siegel RM, Johnson M, Lenardo MJ, Puck JM, Fleisher TA. Immunophenotypic profiles in families with autoimmune lymphoproliferative syndrome. Blood. 2001;98(8):2466-73. https://doi.org/10.1182/blood.v98.8. 2466.

60. van den Berg A, Rienk Tamminga R, Debora de Jong D, Ewerton Maggio E, Willem Kamps W, Sibrand Poppema S. FAS gene mutation in a case of autoimmune lymphoproliferative syndrome 
type IA with accumulation of gammadelta+ T cells. Am J Surg Pathol. 2003;27(4):546-53. https://doi.org/10.1097/00000478200304000-00017.

61. Holzelova E, Vonarbourg C, Stolzenberg MC, Arkwright PD, Selz F, Prieur AM, Blanche S, Bartunkova J, Vilmer E, Fischer A, Le Deist F, Rieux-Laucat F. Autoimmune lymphoproliferative syndrome with somatic Fas mutations. N Engl J Med. 2004;351(14):1409-18. https://doi.org/10.1056/NEJMoa040036.

62. Bristeau-Leprince A, Mateo V, Lim A, Magerus-Chatinet A, Solary E, Fischer A, Rieux-Laucat F, Gougeon ML. Human TCR alpha/beta+ CD4-CD8- double-negative T cells in patients with autoimmune lymphoproliferative syndrome express restricted Vbeta TCR diversity and are clonally related to CD8+ T cells. J Immunol. 2008;181(1):440-8. https://doi.org/10.4049/jimmunol. 181.1.440.

63. Wang J, Zheng L, Lobito A, Chan FK, Dale J, Sneller M, Yao X, Puck JM, Straus SE, Lenardo MJ. Inherited human caspase 10 mutations underlie defective lymphocyte and dendritic cell apoptosis in autoimmune lymphoproliferative syndrome type II. Cell. 1999;98(1):47-58. https://doi.org/10.1016/S0092-8674(00) 80605-4.

64. Sieling PA, Porcelli SA, Duong BT, Spada F, Bloom BR, Diamond B, Hahn BH. Human double-negative T cells in systemic lupus erythematosus provide help for $\mathrm{IgG}$ and are restricted by CD1c. J Immunol. 2000;165(9):5338-44. https://doi.org/10.4049/ jimmunol.165.9.5338.

65. Bezbradica JS, Hill T, Stanic AK, Van Kaer L, Joyce S. Commitment toward the natural $\mathrm{T}$ (iNKT) cell lineage occurs at the CD4+8+ stage of thymic ontogeny. Proc Natl Acad Sci U S A. 2005;102(14):5114-9. https://doi.org/10.1073/pnas.0408449102.
66. Kronenberg M, Engel I. On the road: progress in finding the unique pathway of invariant NKT cell differentiation. Curr Opin Immunol. 2007;19(2):186-93. https://doi.org/10.1016/j.coi.2007. 02.009 .

67. Galli G, Pittoni P, Tonti E, Malzone C, Uematsu Y, Tortoli M, Maione D, Volpini G, Finco O, Nuti S, Tavarini S, Dellabona P, Rappuoli R, Casorati G, Abrignani S. Invariant NKT cells sustain specific B cell responses and memory. Proc Natl Acad Sci U S A. 2007;104(10):3984-9. https://doi.org/10.1073/pnas.0700191104.

68. Van Kaer L. NKT cells: T lymphocytes with innate effector functions. Curr Opin Immunol. 2007;19(3):354-64. https://doi.org/10. 1016/j.coi.2007.03.001.

69. Tupin E, Kinjo Y, Kronenberg M. The unique role of natural killer $\mathrm{T}$ cells in the response to microorganisms. Nat Rev Microbiol. 2007;5(6):405-17. https://doi.org/10.1038/nrmicro1657.

70. Yamamura T, Sakuishi K, Illés Z, Miyake S. Understanding the behavior of invariant NKT cells in autoimmune diseases. J Neuroimmunol. 2007;191(1-2):8-15. https://doi.org/10.1016/j.jneur oim.2007.09.014.

71. Miyake S, Yamamura T. NKT cells and autoimmune diseases: unraveling the complexity. Curr Top Microbiol Immunol. 2007;314:251-67. https://doi.org/10.1007/978-3-540-69511-0_ 10.

Publisher's Note Springer Nature remains neutral with regard to jurisdictional claims in published maps and institutional affiliations. 